Vol. 2, No. 2, December 2021

\section{SPEKTA}

Jurnal Pengabdian Kepada Masyarakat : Teknologi dan Aplikasi

Journal homepage :

http://journal2.uad.ac.id/index.php/spekta

\title{
IMPLEMENTATION OF HEALTHY AND CLEAN LIFESTYLES (PHBS) THROUGH THE ERGONOMIC HANDS WASHER AND SANITIZER
}

\author{
Dheasy Herawati ${ }^{1}$, Nurul aziza ${ }^{2, *}$, Setyawan ${ }^{3}$ \\ ${ }^{1}$ Department of Health Science, Universitas Maarif Hasyim Latif, Indonesia. \\ ${ }^{2}$ Department of Industrial Engineering, Universitas Maarif Hasyim Latif, Indonesia \\ ${ }^{3}$ Department of Management, Universitas Maarif Hasyim Latif, Indonesia
}

\begin{tabular}{l}
\hline ARTICLE INFO \\
\hline \\
Recived : April, 2021 \\
Revised : August, 2021 \\
Accepted : August, 2021 \\
\hline
\end{tabular}

Keywords:

ergonomic;

hand washing;

pandemic;

community.

\begin{abstract}
As a form of community service during this current Covid-19 pandemic, Universitas Maarif Hasyim Latif appointed several UMAHA Task Forces in collaboration with NU MWC Task Forces in Sidoarjo area as a form of concern to participate in the Clean and Healthy Lifestyle (PHBS) movement by providing counseling and assistance with ergonomic handwashing tools. This handwashing tool is designed without touching the water faucet and soap holder as a medium that is suspected of spreading the virus. As the result, the counseling and distributing pamphlets affected on the residents' understanding towards PHBS of around 46.7\%. At the same time, user satisfaction with the ease of the tool is 46.2\%. Simultaneous counseling needs to be done to slowly change the local community ways of thinking and behavior. While in terms of design, hand washing equipment still requires to be developed more with the addition of sensors.
\end{abstract}

\section{INTRODUCTION}

The Indonesian government stated that a total of 3,532,567 people were confirmed positive for COVID-19 based on reports as of August 4, 2021 (Kemenkes, 2021). There are two transmission media for the spread of the COVID-19. It might be through droplets in the respiratory tract and physical contact. Various actions have been adopted by the Ministry of Health of the Republic of Indonesia aimed at tackling the increasing spread of COVID-19 with reference to the WHO on the novel Coronavirus (WHO, 2021). Using hand soap and clean running water, covering the nose and mouth when sneezing, reducing direct physical contact with humans or animals with signs of respiratory disease are the recommended advice to prevent the spread of infection. When at the location of health facilities, especially the Emergency Unit (UGD) area, it is necessary to implement Infection Prevention and Control (PPI) while still complying with health protocols by

\footnotetext{
* Corresponding author.

E-mail address: nurul_aziza@dosen.umaha.ac.id

https://doi.org/10.12928/J.spekta.v2i2.4012
} 
wearing masks, keeping the distance, and always washing hands with soap (Kemenkes, 2021).

The prone transmitting locations of COVID-19 are crowded places such as markets and modern shopping centers. The number of COVID-19 cases among market traders continues to grow as the number of tests increases. Based on research that the majority of people still do not have a good understanding of the need for handwashing with soap related to the correct way to wash hands and the time it takes to form good handwashing behavior (Sinaga, Munthe, \& Bangun, 2020). However, washing hands using soap and hand sanitizer is effective in reducing the number of germs (Desiyanto \& Djannah, 2013). In other words, there is a strong relationship between knowledge and handwashing behavior (Lestari, 2019). The behavior of always washing hands and implementing Healthy and Clean Lifestyles (PHBS) are strategies that can prevent the spread of Covid19 (Karo, 2020). Washing hands with soap and running water for 20 seconds is one of the prevention methods that can be done to reduce the risk of transmitting the Covid-19 virus (Risfianty \& Indrawati, 2020). Efforts made to reduce the possibility of infected Covid19 are by reducing the intensity of touching your face after traveling or touching items in public areas, social distancing, using masks, spraying disinfectants, using hand sanitizers, and washing hands with soap and running water after traveling (Larasati \& Haribowo, 2020). Washing hands with soap properly is determined by one's own behavior. A healthy lifestyle will describe a good quality of life (Risnawaty, 2016). This handwashing activity with soap requires public places to provide handwashing facilities that not only provide water but also have to provide special soap. The results of the study indicate that there is an increase in public awareness of washing hands with germ sanitizer and clean running water (Jannah, 2020). In-service activities in Bengkulu, education about PHBS has been provided, from the results of activities in the form of counseling and media posters, there has been an increase in understanding about PHBS (Zukmadini, Karyadi, \& Kasrina, 2020). PHBS counseling activities were also carried out in Kemantren Village. (Rofiki \& Famuji, 2020). The behavior of early childhood at RA Lab school IAIN Pekalongan also shows high enthusiasm in efforts to prevent the spread of COVID-19 (Tabi'in, 2020). Getting used to washing hands with soap or hand sanitizer at all times is a PHBS behavior that can help prevent the spread of COVID-19 (Karo, 2020). The various service activities above only focus on PHBS counseling activities, but there are no community service activities that contribute to handwashing tools that can help the community as a medium for washing hands to minimize the transmission of the COVID-19.

Therefore, this community service program in Tarik village involves MWC NU Tarik as a direct driving force to the community. It is to implement a Clean and Healthy Lifestyles (PHBS) in preventing the spread of COVID-19 through outreach activities. This counseling focuses on how to use ergonomic handwashing tools. Besides, it also focuses on the well-practiced of using hand sanitizers. This community service is also based on the design of portable handwashing machines (Saputra, Pamasaria, Wiratmoko, Hermawan, \& Supriyono, 2020). However, it's simplified so that the local community can easily use it without electrical energy. It is hoped that after this community service activity, public awareness and knowledge about PHBS can slowly increase. It is aimed at reducing the spread of the Covid-19. Besides, it's also hoped that this program will increase community satisfaction during using the handwashing tool. 
Vol. 2, No. 2, December 2021

\section{METHOD}

Implementation of Community Service activities at Maarif Hasyim Latif University with the theme "Socialization of Healthy Lifestyles and Covid-19 Prevention at MWC NU Tarik". PKM activities are carried out in 3 stages, namely the preparation stage, the implementation stage and the completion stage. The method of implementing this activity can be described in the flow chart in figure 1.

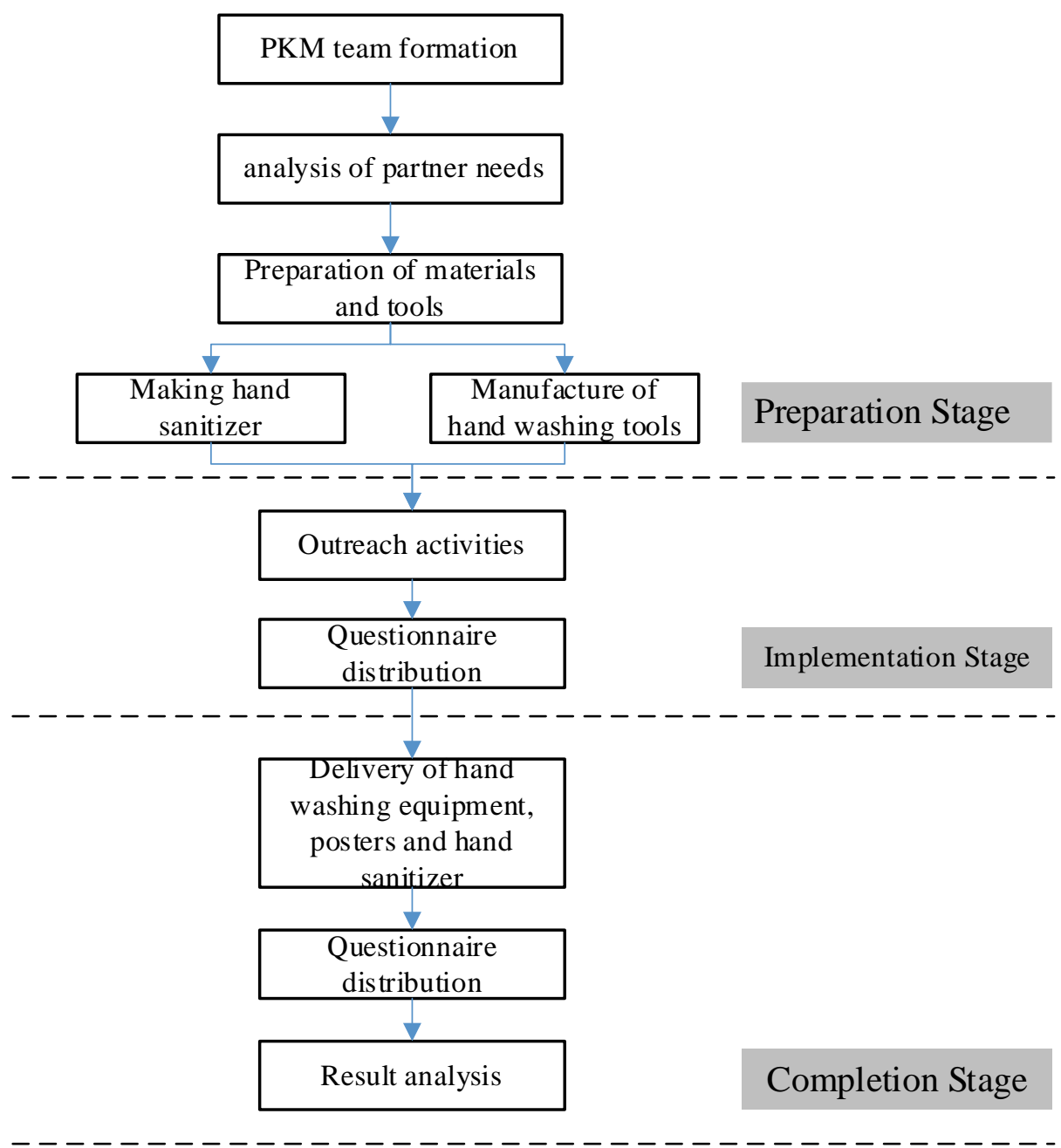

Figure 1. The Program Flowchart

\section{A. Preparation Stage}

At this stage, an analysis of the needs of partners is conducted by reviewing the proposal letter for requesting assistance. Once it's done, then it was followed by preparing materials and tools needed in providing assistance to partners, including the manufacture of handwashing tools and hand sanitizers. The hand sanitaizer making process can see in the figure 2 and manufacture of hand washing can see in figure 3. 
SPEKTA

Jurnal Pengabdian Kepada Masyarakat : Teknologi dan Aplikasi

Vol. 2, No. 2, December 2021

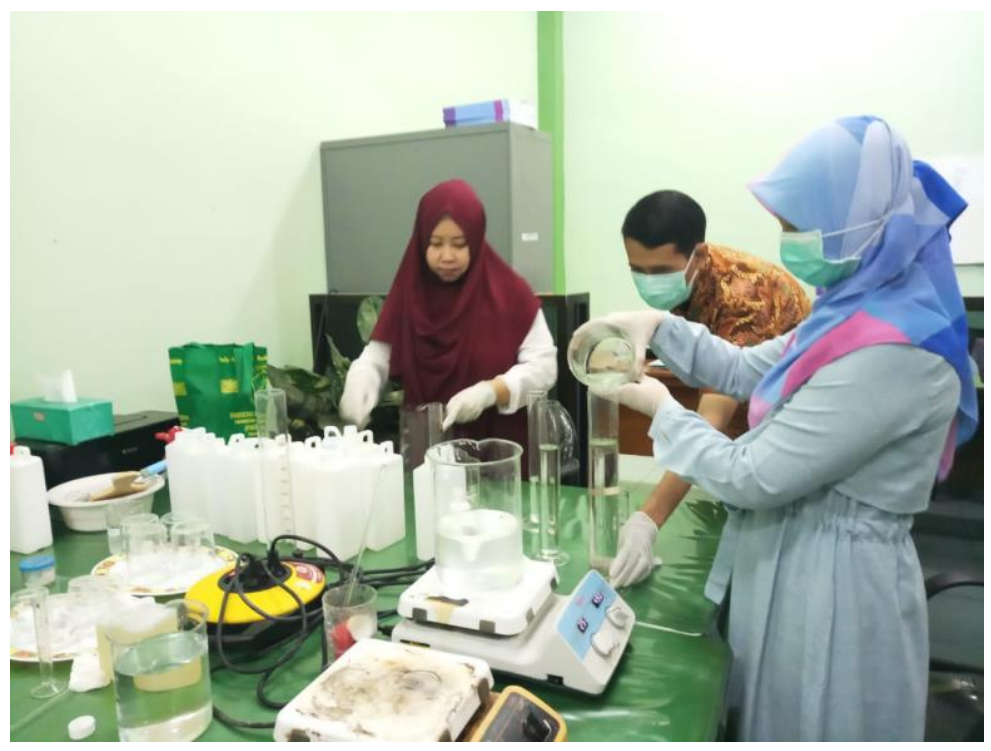

Figure 2. The Hand Sanitizer making process

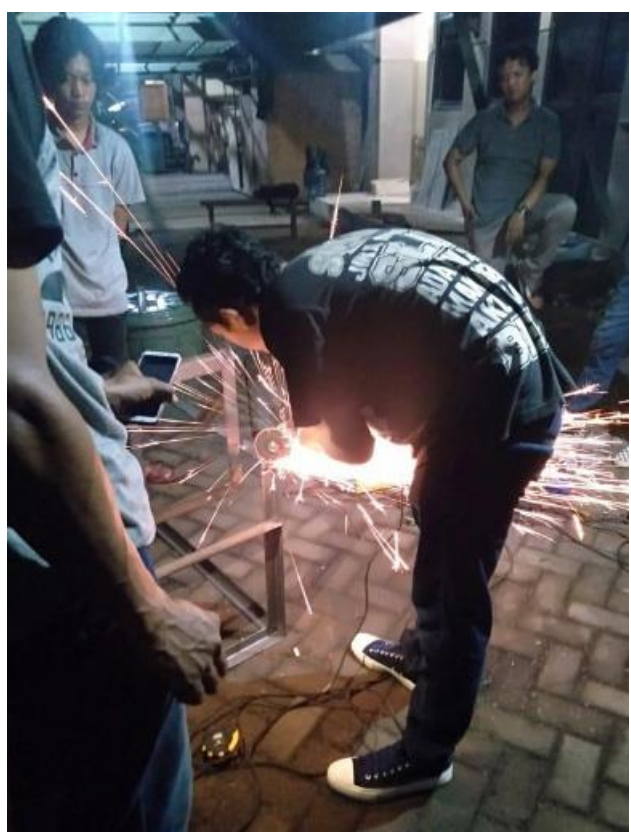

Figure 3. The process of handwashing media construction

B. The Implementation Stage

The PKM (Community Service) program under the theme of socializing PHBS and Covid Prevention in collaboration with the MWC NU Tarik Covid-19 Task Force started with the manufacturing process of handwashing tools that was carried out by the Faculty of Engineering.

C. The Completion Stage

This stage included the handover of handwashing equipment and outreach activities to the community about Healthy and Clean Lifestyles (PHBS) as it becomes the man purposes of the program. 
Vol. 2, No. 2, December 2021

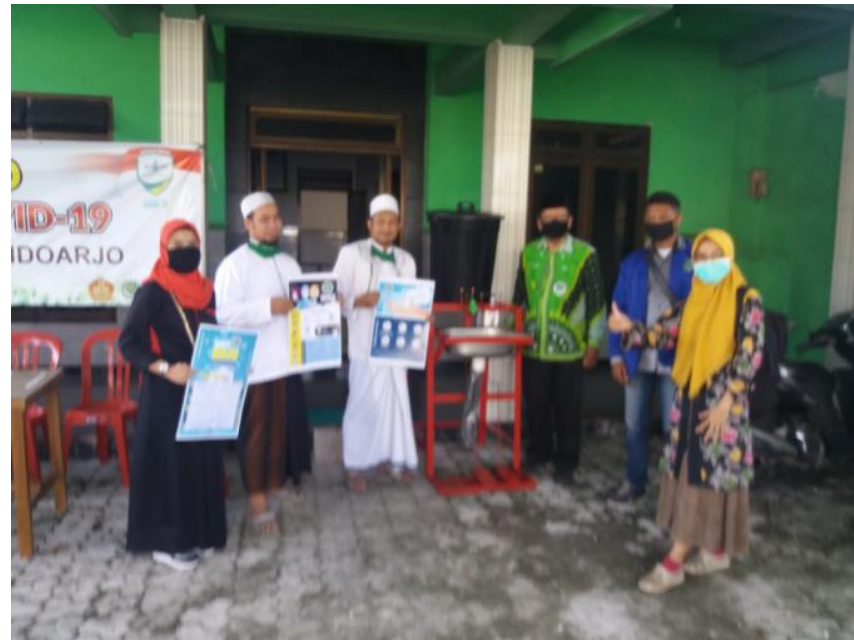

Figure 4. The handover agenda of handwashing equipment, pamphlet and hand sanitizer

\section{RESULTS AND DISCUSSION}

The current program of the community service is more focused on efforts to implement PHBS in partnership with the Covid-19 task force of the Branch Representative Council (MWC) NU at Tarik Village. The activities are including handing over a set of handwashing tools, pamphlets, and hand sanitizer (figure 5). The efforts to prevent COVID-19 must be carried out by all elements. It should become a collaborative work from the government, educational institutions, community organizations, and all residents. Everyone must work together to face the COVID-19 pandemic.

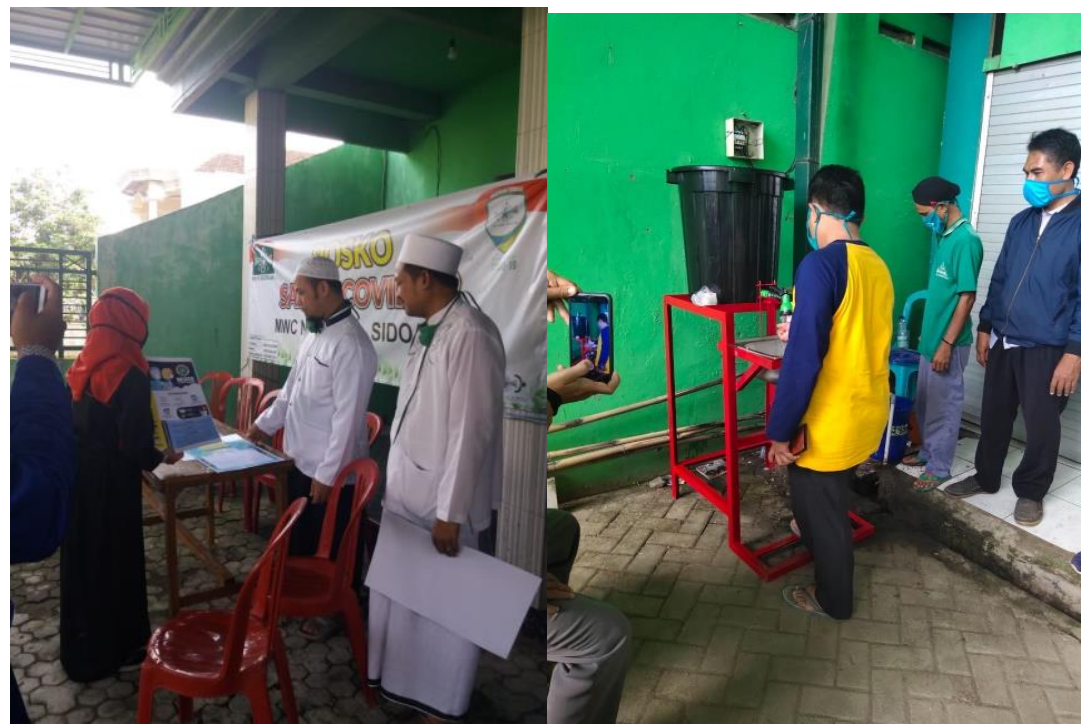

Figure 5. The demonstration process of the Clean and Healthy Lifestyle (PHBS)

This community service program becomes a real effort of UMAHA's concern for the community to increase public awareness and knowledge about Clean and Healthy Lifestyle (PHBS). The socialization of the PHBS in this community service activity was carried out by counseling and PHBS demonstrating process. Besides, it was also conducted by distributing pamphlets to the local community to avoid crowds. It was all to avoid face-to-face meetings and direct socialization activity. The information 
Vol. 2, No. 2, December 2021

contained in the pamphlet is expected to increase knowledge and educate people to obey the health protocols in preventing and controlling COVID-19. Based on the results of the questionnaire, the understanding of the community in Tarik Village towards PHBS might be seen through the figures 6 .

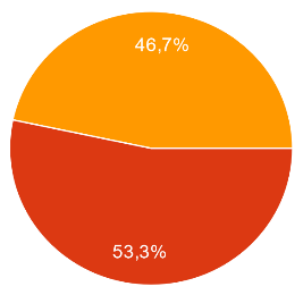

(a). PHBS Understanding

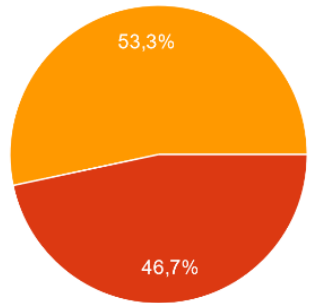

(c) The understanding on how to keep the house and enviroment

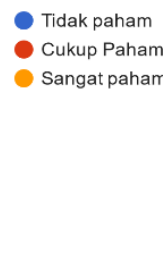

Tidak paham Sangat paham

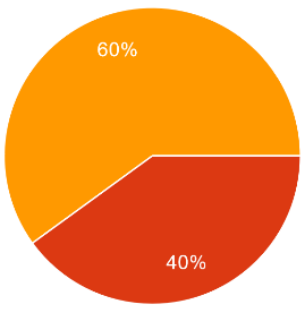

(d) The awareness of handwashing with the soap and handsanitizer
Tidak paham

Cukup Paham Sangat paham (b). The understanding of proper and safe handwashing

Figure 6. Questionnaire results the understanding of the community in Tarik Village towards PHBS

However, it turned out that after counseling about PHBS, the local community in the Tarik village started to concede about PHBS by $53.3 \%$ and were accustomed to washing their hands with soap and running water or using hand sanitizer by $60 \%$. With this outreach activity, it is hoped that the local community will carry out health protocols independently and consciously. It might be realized by getting into the habit of washing hands with soap and running water or using hand sanitizers. While the results of the questionnaire on the use of ergonomic handwashing tools can be in figure 7.

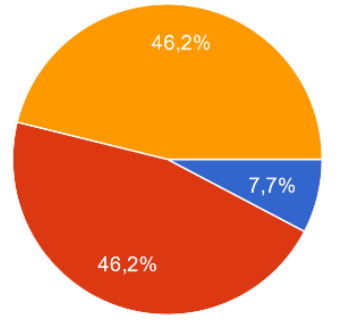

(a) The tool's ease
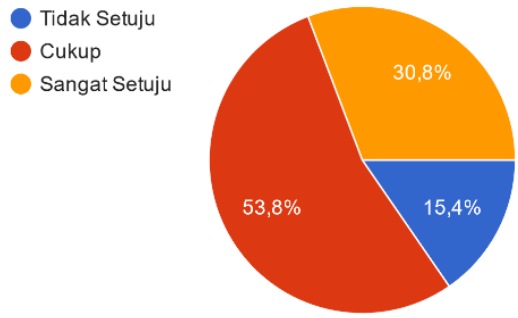

(b) Height suitability of body position and tools 
Vol. 2, No. 2, December 2021

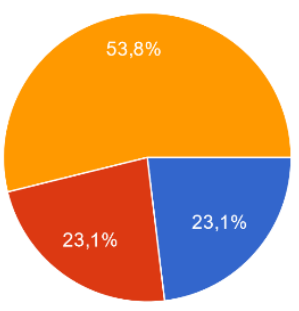

(c) The comfortable footing position for feet

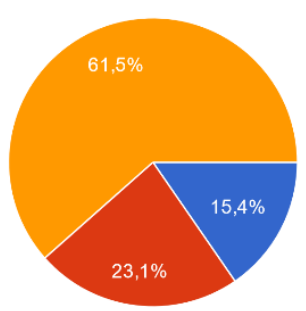

Tidak Setuju Cukup Sangat Setuju

(d) The water and soap easily come out when stepped

on

Figure 8. The use of ergonomic handwashing tools

Based on the results of the questionnaire, the use of hand washing equipment can be categorized under quite ergonomic because it does not touch the faucet or soap dispenser. However, there are needs to be improved in the shortcomings related to user response. It is found that the footing is still not fully comfortable to use.

\section{CONCLUSION}

The results of community service activities concerning the prevention and control of the covid-19 might be concluded at an average rate. The socialization activities through counseling and pamphlets addressed to the local community regarding Clean and Healthy Lifestyles (PHBS) have not been able to have a significant impact on the community. To get a comprehensive understanding of citizens on PHBS, it is necessary to conduct counseling simultaneously for the long term so that local community behavior slowly changes. As for handwashing tools, improvements need to be made in the form of design so that the tools can function optimally. In the future, it may be necessary to design hand washing equipment using sensors or other technologies.

\section{ACKNOWLEDGEMENT}

The authors would like to express their gratitude and thanks to the head of LPPM Universitas Maarif Hasyim Latif, the Faculty of Engineering, the Faculty of Economic and Business, the Faculty of Health Science, and also the Faculty of Law for the funding, ideas and all supports to this community service.

\section{REFERENCES}

Desiyanto, F. A., \& Djannah, S. N. (2013). Efektivitas mencuci tangan menggunakan cairan pembersih tangan antiseptik (hand sanitizer) terhadap jumlah angka kuman. Kes Mas: Jurnal Fakultas Kesehatan Masyarakat Universitas Ahmad Daulan, 7(2), 24934.

Jannah, S. H. (2020). Perilaku Hidup Bersih Dan Sehat (Phbs) Di Masa Pandemi. In Seminar Nasional Hasil Pengabdian Kepada Masyarakat (Vol. 4, pp. 194-198).

Karo, M. B. (2020). Perilaku Hidup Bersih dan Sehat (PHBS) Strategi Pencegahan Penyebaran Virus Covid-19. In Prosiding Seminar Nasional Hardiknas (Vol. 1, pp. $1-4)$.

Larasati, A. L., \& Haribowo, C. (2020). Penggunaan Desinfektan dan Antiseptik Pada Pencegahan Penularan Covid-19 di Masyarakat. Majalah Farmasetika, 5(3), 137145.

Lestari, A. O. A. W. (2019). Hubungan pengetahuan dan sikap terhadap perilaku cuci tangan pada masyarakat Kelurahan Pegirian. Jurnal Promkes: The Indonesian 
Vol. 2, No. 2, December 2021

Journal of Health Promotion and Health Education, 7(1), 1-11.

Risfianty, D. K., \& Indrawati, I. (2020). Pemberdayaan Kesehatan Masyarakat Melalui Pengadaan Fasilitas Cuci Tangan pada Masa Pandemi Covid-19 di Masjid dan Mushala Dusun Montong Are Tengah. Jurnal Pengabdian UNDIKMA, 1(2), 94-99.

Risnawaty, G. (2016). Faktor determinan perilaku cuci tangan pakai sabun (CTPS) pada masyarakat di tanah kalikedinding. Jurnal Promkes: The Indonesian Journal of Health Promotion and Health Education, 4(1), 70-81.

Rofiki, I., \& Famuji, S. R. R. (2020). Kegiatan Penyuluhan dan Pemeriksaan Kesehatan untuk Membiasakan PHBS bagi Warga Desa Kemantren. Dinamisia: Jurnal Pengabdian Kepada Masyarakat, 4(4), 628-634.

Saputra, T. H., Pamasaria, H. A., Wiratmoko, B., Hermawan, R., \& Supriyono, R. (2020). Rancang Bangun Mesin Cuci Tangan Otomatis Portabel untuk Mengurangi Efek Pandemi Covid 19. LOGISTA-Jurnal Ilmiah Pengabdian Kepada Masyarakat, 4(2), 534-540.

Sinaga, L. R. V., Munthe, S. A., \& Bangun, H. A. (2020). Sosialisasi perilaku cuci tangan pakai sabun di desa sawo sebagai-bentuk kepedulian terhadap masyarakat ditengah mewabahnya virus covid-19. Jurnal Abdimas Mutiara, 1(2), 19-28.

Tabi'in, A. (2020). Perilaku Hidup Bersih dan Sehat (PHBS) pada Anak Usia Dini sebagai Upaya Pencegahan Covid 19. JEA (Jurnal Edukasi AUD), 6(1), 58-73.

Zukmadini, A. Y., Karyadi, B., \& Kasrina, K. (2020). Edukasi Perilaku Hidup Bersih dan Sehat (PHBS) dalam Pencegahan Covid-19 kepada Anak-anak di Panti Asuhan. Jurnal Pengabdian Magister Pendidikan IPA, 3(1). 